\title{
LIDIJA TANUŠEVSKA
}

(D) https://orcid.org/0000-0001-5465-960X

Uniwersytet św. św. Cyryla i Metodego

Skopje

\section{Tłumaczenie tłumaczenia (czyli William Blake w powieści Olgi Tokarczuk)}

\author{
Translating the translation (O. Tokarczuk $v$ William Blake)
}

\begin{abstract}
The paper discusses the connection between Olga Tokarczuk's novel Drive Your Plow over the Bones of the Dead and the poetry of William Blake. Blake's ideology was to show how mankind had come to the end because of its misdeeds, using the animal imagery, which links him to the topic presented by Tokarczuk, criticizing the cruelty of the authorities towards animals. She quoted Blake at the beginning of every chapter and created a character skilled in translating Blake. Since not much of Blake's oeuvre has been translated in Macedonian, the translator of this novel had to deal with translating Blake too. Consequently, this text also focuses on the translation problems which she had to solve.
\end{abstract}

Key words: Blake, Tokarczuk, translation, poetry

Powieść Prowadź swój plug prz̨ez kości umarlych, wydana w 2009 roku, została uznana za jeden z najbardziej zaangażowanych utworów Olgi Tokarczuk. To krytyka społeczna i unaocznienie wszechobecnego wkładu człowieka w niszczenie przyrody. Autorka umiejętnie zastosowała tu znany w literaturze chwyt połączenia niskiego gatunku, kryminału i thrillera, z wysokimi ambicjami przekazu, czyli kwestionowaniem zasad filozoficzno-moralnych współczesnego świata. Ukryte podłoże powieści stanowią zmarginalizowane postaci, nieudacznicy, którzy nie zrobili kariery, polemika z poglądami katolickimi, piękno krainy bliskiej pisarce, portret ludzkiej natury, marzenie o świecie lepszym niż ten, w którym żyjemy, bardziej sprawiedliwym, intuicyjnym i duchowym. Jednak nie można oprzeć się wrażeniu, że główną rolę w powieści odgrywają zwierzęta. Obraz zwierząt i metaforykę, mającą swe podstawy doświadczeniowe w ich świecie, wykorzystano, żeby pokazać bez- 
litosne, podłe i skorumpowane zachowanie istoty ludzkiej, które spowodowało, że człowieczeństwo zawisło na krawędzi bezładu.

To ostatnie twierdzenie znajdziemy także w opisach poezji Williama Blake’a, którego Olga Tokarczuk nieprzypadkowo wybrała na „patrona” tej opowieści. Tak samo jak u angielskiego prekursora romantyzmu, w książce polskiej pisarki słychać proroczy głos narratorki i głównej bohaterki Janiny Duszejko, który zamknięty w ramy społecznego dyskursu staje się coraz dalszy i niezrozumiały dla świata, do którego się zwraca. Motywem przewodnim w poezji Blake’a jest poszukiwanie jedności. Pojawia się on też w powieści Prowadź swój pług prơez kości umarlych, która odkrywa integralność natury i ducha w życiu wybranych postaci, takich jak: Janina Duszejko, Matoga, Dobra Nowina, Dyzio. Żyją oni inaczej niż pozostali mieszkańcy sudeckiej krainy - odizolowanej, ale będącej wciąż pod wielkim wpływem państwowej i globalnej polityki. Blake też ciagle podkreślał dwa stany ludzkiej duszy: zetknięcie się niewinności i doświadczenia; wskazywał na ich połączenie jako budulec swoich wierszy. Ciagle poszukiwał androgyne jako całości złożonej z dwóch rodzajów ludzkiego nastroju. Niewinność reprezentowana jest tu przez zachwyt i gorliwość, a doświadczenie skłania ku rozpaczy i smutkowi. Taką jedność spróbowała stworzyć także Olga Tokarczuk, łącząc ze sobą postaci emerytowanej pani inżynier i informatyka z gminnego posterunku policji. Janina Duszejko to starsza kobieta, która jest skłócona z całym światem, a z tego powodu jej rozsądkiem kieruje rozpacz, dokuczaja jej różne dolegliwości, jest smutna i samotna. Z kolei Dyzio jest młodym człowiekiem, trochę naiwnym i z tego powodu niewinnym, wiele rzeczy go jeszcze zachwyca, oddaje się swoim zamiłowaniom z zapałem. Tych dwoje połączy przyjaźń, ale jest w tej relacji też coś więcej; choć są to charaktery bardzo sprzeczne, pojawia się między nimi więź porozumienia, której właściwie nie da się wytłumaczyć. Ostatecznie rozpacz i spór ze światem prowadzi do przekroczenia granicy między dobrem a złem, co także odnajdujemy w wierszach Blake’a. Poszukiwanie sprawiedliwości budzi w bohaterce książki chęć do odbierania ludzkiego życia, ilekolwiek by ono nie było warte.

Angielski poeta w wierszach ujawnia swoje postawy wobec otaczającego świata. Cytaty z Blake’a na początku każdego rozdziału powieści Tokarczuk oraz tytuł książki dobrane są tak, że zdają się wyrażać stanowisko pisarki wobec spraw dziejących się wokół niej. Autorka głosem narratorki mówi w powieści: „nie rozumiałam nic z tych pięknych, dramatycznych obrazów, które Blake wyczarowywał słowami. Czy on tak myślał naprawdę? Co opisywał? Gdzie to jest? Gdzie to się dzieje i kiedy? Czy to jest baśń czy mit?” 
(Tokarczuk 2016, 89). Czy to ona sama nie jest pewna swojego rozumienia Blake’a, czy wczuwa się w postawę czytelnika, który, rozumiejąc Tokarczuk, nie musi koniecznie rozumieć Blake’a? W powieści Dyzio amatorsko, choć z gorliwością, przekłada swojego ulubionego poetę i prosi Janinę Duszejko, jako byłą nauczycielkę angielskiego, o pomoc. Współuczestniczy ona w tłumaczeniu, choć twierdzi: „Nie lubiłam poezji i wszystkie wiersze świata wydawały mi się niepotrzebnie skomplikowane i niejasne. Nie rozumiałam, dlaczego tych rewelacji nie zapisuje się po ludzku - prozą" (Tokarczuk 2016, 89). Olga Tokarczuk często mówi o kluczowej roli tłumaczy swoich utworów. Noblistka podkreśla, że czuje, iż jest elementem jakiejś uporządkowanej struktury, ponieważ tłumacze wspólnie z autorami tworzą pewien rodzaj wspólnoty, inspirując się wzajemnie w niezwykle intensywny sposób. Dzięki tej współpracy sam proces przekładu wydaje się dla pisarki czymś znanym, bliskim. Pokazuje to, opowiadając o Dyziu jako tłumaczu: „Szybko kojarzył i potrafił spojrzeć na tłumaczone zdanie z zupełnie innej strony, zostawić na boku niepotrzebne przywiązanie do słowa, odbić się od niego i powrócić z czymś zupełnie nowym, pięknym” (Tokarczuk 2016, 89).

Czyje to słowa? Olgi Tokarczuk-pisarki? Czytelnika poszukującego ukrytych nauk Blake'a wplecionych w tekst? Tłumacza powieści na inny język? Muszę przyznać, że w zacytowanych słowach odnalazłam siebie, kiedy przekładałam Prowadź swój pług przę kości umarlych na język macedoński. Poza specjalistycznymi nazwami owadów największym wyzwaniem translatorskim były dla mnie właśnie cytaty z poezji Blake’a i opisywany proces tłumaczenia wersów z Mentalnego travellera na stronach 114 i 115, ponieważ większość z nich nie została jeszcze przełożona na macedoński. Początkowo kierowałam się zasadami Stanisława Barańczaka dotyczącymi tłumaczenia poezji amerykańskiej: „tłumacz każdy wyraz dosłownie i z osobna, albo (jeszcze lepiej) wymyśl na własną rękę coś zupełnie innego (...) drogowskazem (...) niechaj ci będzie niezawodna słowiańska intuicja” (Barańczak 2004, 133 134). Korzystałam więc z przekładu polskiego, który dosłownie tłumaczyłam na macedoński, a tam, gdzie rym nie pasował, „wymyślałam coś innego”. Przy tym ujawniały się dylematy związane z poprawnością językową, ale - jak mówi słynny poeta tłumacz - „nie daj sobie wmówić, że w poezji istnieje coś takiego jak poprawność językowa” (Barańczak 2004, 137). Była to spontaniczna próba tłumaczenia wersów z Blake’a, do których dopracowania miałam wrócić w następnym etapie przekładu, kierując się ponownie słowami Barańczaka: „erudycja, jak wiadomo, zabija spontaniczność, a cóż cenniejszego nad spontaniczność przy tłumaczeniu poezji” (Barańczak 2004, 136). Poezja 
uważana jest w zasadzie powszechnie za przykład nieprzekładalności. Tłumaczenie poezji jest więc złem koniecznym, czymś z założenia niepełnym, w najlepszym wypadku - przybliżeniem, a sam proces tłumaczenia jest w gruncie rzeczy serią ustępstw i kompromisów. W dyskursie przekładoznawczym dotyczącym poezji granica między koniecznością a przypadkiem jest dalece zatarta, trudno więc orzec, co musi być spełnione jako bezwzględny nakaz, a co będzie tolerowane jako szczęśliwy incydent (Święch 2016, 27-28). Zdaje sobie sprawę z tego także Olga Tokarczuk, pisząc:

Bo jak przetłumaczyć wyliczankę, którą mogłyby rozpoczynać grę małe dzieci, zamiast ciagle recytować „Pałka zapałka dwa kije”:

Every Night \& every Morn

Some to Misery are Born

Every Morn \& every Night

Some are born to sweet delight,

Some are born to Endless Night.

To najsłynniejszy wierszyk Blake’a. Nie da się go przetłumaczyć na polski, żeby nie zgubić rytmu, rymu i dziecięcej lakoniczności (Tokarczuk 2016, 90).

Próby przekładania go przez Dyzia pisarka nazywa „rozwiązywaniem szarady", a jako dowód na nieprzekładalność zostawia ten wierszyk w oryginale, bez tłumaczenia na język polski.

Wracając do procesu tłumaczenia, jaki jest nakreślony w powieści Prowadź swój plug præez kości umarlych, można stwierdzić, że dotyczący go fragment ujawnia fachową wiedzę przekładoznawczą autorki, zaczerpniętą z praktyki prawdziwego tłumacza. Narratorka tak ów proces opisuje: „Najpierw każde z nas pisało swoją wersję, potem porównywaliśmy i zaczynaliśmy splatać nasze pomysły. Przypominało to trochę grę logiczną, skomplikowane scrabble" (Tokarczuk 2016, 114). Właściwie mowa tu o tym etapie procesu tłumaczenia, kiedy następuje zakodowanie tekstu w języku docelowym. Dochodzi wtedy do podjęcia decyzji i powstania szkicu tłumaczenia, który trzeba dopracować, doszlifować, w którym należy dokonać kosmetycznych zmian. W powieści Prowadź swój plug przę kości umarlych Duszejko i Dyzio tworzą cztery wersje przekładu wiersza, zanim uda im się dojść do ostatecznej. Tłumacząc ten fragment na macedoński, musiałam pokazać te same problemy, z którymi borykają się postaci Tokarczuk. Wśród wyzwań związanych z translacja znalazły się: wybór bardziej eufonicznego słowa, które 
do tego jeszcze współgrałoby z rytmem, rozkład słów w wersie, tak aby dostosować je do rymu, zachowanie treści, znalezienie synonimów itp. Dla ilustracji przytaczam oryginał oraz cztery wersje polskiego przekładu z powieści Prowadź swój pług pržez kości umarlych i cztery moje wersje przekładu macedońskiego.

(ang.) I travel'd thro' a Land of Men

A land of Men \& Women too,

And heard \& saw such dreadful things

As cold Earth wanderers never knew

1. (pol.) Zjeździłem całą Ludzką Ziemię

Kraj Mężczyzn oraz Kobiet

Widząc i słysząc straszne Rzeczy

że nikt ich nawet nie wypowie

(mac.) *Ја поминав целата Човечка Земја

Земја на Мажи и Жени

ГАеАајќи и слушајќи Работи страшни

Што никој не може Аури ни да ги раскаже ${ }^{1}$

Pierwsza wersja jest przekładem najbardziej dosłownym zarówno po polsku, jak i po macedońsku, bo głównym celem tłumaczenia jest przekazanie znaczenia. W wersji macedońskiej widać wpływ wiersza w języku polskim i naśladowanie pokrewnej, słowiańskiej struktury składniowej. Pod wpływem polskiego przekładu w macedońskim tekście pozostawiono formy imiesłowu przysłówkowego, które nie pojawiają się w oryginale, oraz zdanie dopełniające w ostatnim wersie, którego też nie ma u Blake’a. Jeśli chodzi o rym, w polskim przekładzie zachowano w pewnym stopniu odpowiedniość w stosunku do oryginału (rymowanie drugiego i czwartego wersu), a w macedońskim - póki co - nie ma go w ogóle.

2. (pol.) Przemierzałem Ludzką Ziemię

Krainę Mężzzyzn i Kobiet

Słysząc i Widząc tak straszne rzeczy

Jakich nie poznał dotąd żaden Człowiek

${ }^{1}$ Gwiazdką zaznaczam wszystkie przekłady po macedońsku, ponieważ tłumaczenie powieści Prowadź swój plug pržez kości umarlych istnieje nadal tylko w wersji roboczej, nieostatecznej i niepublikowanej. 
(mac.) *Ја прошетав Земјата Човечка

Крајот на Мажи и Жени

Слушнав и Видов работи толку страшни

Што Аотогаш ниеден Човек не ги дознал

W drugiej wersji podkreślone zostały fragmenty wiersza, które różnią się od pierwszego tłumaczenia. Trzeba wziąć pod uwagę, że przekłady Duszejko i Dyzia nie mogły być jednakowe. Różnice nie są znaczące, to na przykład: dobór bliskoznacznego wyrazu, inwersja imiesłowów, małe odchylenie od oryginału w ostatnim wersie, dokonane w celu dostosowania się do rymu. W języku macedońskim wprowadzono dodatkową zmianę szyku trzeciego wersu (fragment pogrubiony), który jest bardziej poetycki, ale mniej poprawny językowo, nadal jednak brakuje rymu.

3. (pol.) Podróżowałem poprzez całą Ziemię,

Zmierzyłem Ziemię Mężczyzn oraz Kobiet

Widząc i słysząc Rzeczy wprost potworne

Jakich nie poznał dotąd żaden Człowiek.

(mac.) *Пропатував низ целата Земја,

Ја поминав земјата на Мажи и Жени

ГАедајќи и слушајќи чудовишни нешта

Што Аотогаш ниеден човек не ги знае.

W trzeciej wersji polskiego przekładu już widać, że tekst nabiera powoli ostatecznego kształtu, wersy są wyrównane, nadążają za rytmem, ale rym nie jest jeszcze wystarczająco dopracowany. W macedońskiej wersji spróbowano zrobić to samo, a dodatkowa zmiana pojawia się w ostatnim wersie, ale i tym razem czasownik ,знаe " nie tworzy rymu ze słowem z drugiego wersu.

4. (pol.) Wędrowałem poprzez męskie kraje,

Przez męskie i kobiece obszary

I rzeczy straszne tam ujrzałem,

Którym nikt na ziemi nie daje wiary

(mac.) *Пропатував по светов многу места

Низ машки и женски предели

И таму видов страшни нешта,

Кои досега никој не ги обвидемил. 
Wreszcie w ostatecznej wersji w języku polskim wiersz został już całkiem przekształcony - zrezygnowano z wierności wobec oryginału, a słowa dobrano do rymu abab, który nawet w oryginale nie jest dokładny w pierwszym i trzecim wersie. W macedońskiej wersji zrobiono to w jeszcze bardziej konsekwentny sposób, zwłaszcza biorąc pod uwage fakt, że w poprzednich wersjach rymu w ogóle nie było.

W powieści Prowadź swój pług præę kości umarlych zamieszczono siedemnaście cytatów z twórczości Blake’a. Część z nich pochodzi z Praystów piekielnych i Pieśni niewinności, ale najwięcej zostało zaczerpniętych z Wróżb niewinności. Z tych wyrywków tylko pięć zostało wcześniej przełożonych na macedoński przez wybitnych tłumaczy z języka angielskiego, znakomitych krytyków literackich, znawców twórczości Blake’a i pisarzy, takich jak Dragi Mihajlovski i Ivan Dżeparoski. Tak więc dla tłumacza prozy polskiej, choć znającego język angielski, kłopotliwe było mierzenie się z przekładem angielskiej poezji romantycznej. Jednakże w pracy nad książką Tokarczuk musiałam podjąć się nad wyraz trudnego przedsięwzięcia tłumaczenia dwunastu wierszy z Wróżb niewinności, które dotąd nie zostały przełożone na macedoński. To wyzwanie pozwoliło mi wszak lepiej zrozumieć powieść Prowadź swój pług pręez kości umartych. W dalszej części omówię kilka problemów tłumaczeniowych, z którymi borykam się do tej pory.

Drugi rozdział książki to historia suki, która była bardzo źle traktowana przez zmarłego w niewyjaśnionych okolicznościach właściciela. Zatem nie przez przypadek mottem wprowadzającym jest tu wyrocznia Blake'a: „Pies, który zdycha z głodu, służąc panu, / Jest zapowiedzą upadłości Stanu”. Tylko o jaki „Stan” chodziło Blake’owi? (po angielsku: „A dog starvd at his Masters Gate / Predicts the ruin of the State"2). Czy mial na myśli „państwo”, „kraj”? Prowadzona przez opowieść o Wielkiej Stopie, na chybił trafił, jak powiedziałby Barańczak, użyłam słowa „gospodarstwo”: * „Песот кој пцовисува оА глаА служејќи му на господарот / Е најава на пропаѓањето на Господарството”. Ponieważ Wielka Stopa został ukarany straszną śmiercią za złe obchodzenie się ze zwierzętami, upada całe jego gospodarstwo. Jednak ze względu na fakt, że postępował on nikczemnie także jako przedstawiciel społeczeństwa, co okazuje się w kolejnych rozdziałach powieści, nasuwa się pytanie, czy lepszą opcją nie byłoby użycie słowa „państwo”. Takie rozwiązanie w języku macedońskim po-

2 Wszystkie oryginalne fragmenty utworów Blake'a pochodzą z https://www.poetryfound ation.org/poems/43650/auguries-of-innocence [dostęp: 25.04.2020]. 
zbawione jest niestety poetyczności i rymu, należy się więc jeszcze nad nim zastanowić.

Czwarty rozdział zaczyna się cytatem: „Ten, kto wątpi w to, co widzi, / Prośby twoje ci wyszydzi. / Słońce i Księżyc, gdyby tak wątpiły, / Z nieba by zaraz ustąpiły”. Słowa te wydają się nawiązywać do sytuacji, w której narratorka opisuje swoje „obchody”, czyli objeżdżanie wszystkich pustych domów, które pozostawiono jej pod opieka, i sprawdzanie w lesie, czy wszystko jest w porządku, czy żadnemu zwierzęciu nie wyrządzono krzywdy. Stojąc na zboczu, Janina Duszejko widziała cały Płaskowyż, ale wiedzę na temat ludzi zamieszkujących te okolice czerpała także z horoskopów. Czy to, co widzi, jest prawdziwe? Czy może czegoś nie dostrzega? Przekład tego cytatu na macedoński to szczęśliwy traf, bo rzeczywiście brzmi jak z Blake’a: * „Оној што се сомнева во тоа што го вилец, / Молбата твоја мајтап ќе му биле. / Сонцето и Месечината, Аа се сомневаа така, / ОА небото веднаш ќе испаднеа без мака". W tym miejscu pojawia się jednak dodatkowo problem wierności przekładu, skoro został on dokonany za pośrednictwem innego języka. Tłumacz na język polski pozwolił sobie bowiem na wolniejszy przekład drugiego wersu: „He who Doubts from what he sees / Will ne'er Believe, do what you Please / If the Sun \& Moon should Doubt / They'd immediately Go out”. W oryginale nie pojawia się „prośba”, tylko słowa: „nigdy nie uwierzy, cokolwiek zrobisz”.

Wiele cytatów odnosi się do wykorzystywania i dręczenia zwierząt oraz kary, która czeka oprawców. Polski przekład czasami okazywał się mylący w procesie tłumaczenia na trzeci język - macedoński: na przykład wyrażenie „las ludzkiej duszy” w motcie wprowadzającym do szóstego rozdziału: „Błąkająca się sarna po lesie / Ludzkiej Duszy niepokój niesie”. Dopiero po porównaniu tego fragmentu z oryginałem (,The wild deer, wandring here \& there / Keeps the Human Soul from Care") zdałam sobie sprawę, że ów „las” w ogóle nie musi się pojawić w przekładzie (nie ma go w oryginale) i powstała, moim zdaniem, lepsza macedońska wersja: * „Аивата срна што ваму-таму талка / Човечката душа со суровост ја валка”. Koń w суtacie rozpoczynającym rozdział siódmy wcale nie musi „tkwić w błocie”: „Koń cięty batem, kiedy w błocie tkwi, / Niebiosa wzywa, żąda ludzkiej krwi””. Oryginał angielski brzmi bowiem: „A Horse misusd upon the Road / Calls to Heaven for Human blood", co w dużej mierze ułatwia tłumaczenie na macedoński: *„На патот застанат коњ, тепан оА стрв, / Небото го моли Аа пролие човечка крв”. We fragmencie wiersza stanowiącym wprowadzenie do dziewiątego rozdziału w polskim tłumaczeniu jest mowa o jakimś 
nieokreślonym ptaku, podczas gdy Blake pisze o skowronku, który w języku macedońskim ma bardzo poetyczną i eufoniczną nazwę: pol. „Gdy trafionemu ptakowi skrzydło martwo zwisa, / śpiew Cherubinów w Niebie się ucisza”; ang. „A Skylark wounded in the wing / A Cherubim does cease to sing”; mac. * Чучулигата слаткопојна погодена во крило,/ пеењето на Херувинот во тишина се свило”. Także w cytacie przed jedenastym rozdziałem w polskim przekładzie znika „rudzik” (i w ogóle „ptak”), o którym mowa w oryginale: „Istoty żywej w klatce uwięzienie / Wprawia Niebiosa w Oburzenie”, ang. „A Robin Red breast in a Cage / Puts all Heaven in a Rage”; mac. * „На црвеногушката слобода ако ѝ земеш, / целото Небо на нозе ќе го кренеш".

$\mathrm{Na}$ tym etapie pracy nad przekładem powieści Olgi Tokarczuk na język macedoński zaniedbano nieco, w pogoni za sensem, strukturę powierzchniowa, czyli dźwiękową i graficzną realizację zdań, która niewątpliwie współtworzy sens i wywiera wpływ na to, co jest ukryte w tekście. Tłumacz bowiem „musi zwrócić uwagę nie tylko na same brzmienia słowne i brzmienia całych zdań czy passusów, lecz także na rytm i tempo, melodię, podobieństwa i kontrasty brzmieniowe" (Kubaszczyk 2016, 23). Przekład powieści Prowadź swój plug przę kości umartych, którym się zajmuję, wymaga jeszcze dużo pracy i wysiłku, ale nawet wtedy, gdy powstanie wersja ostateczna i powieść zostanie wydrukowana, pytanie o ostateczną, zamkniętą formę nie zdezaktualizuje się, bowiem

praca tłumacza przypomina pracę Syzyfa: jest dziełem nigdy niezakończonym (...), niczego nie zamyka, przeciwnie: zaprasza do kontrprzekładu, który zawsze jest dialogiem, do dalszych tłumaczeń tego samego dzieła (...). Istotą pracy tłumacza jest to niedomknięcie (Jarniewicz 2018, 146).

\section{Literatura}

Barańczak S., 2004, Ocalone w ttumaczeniu, Kraków.

Jarniewicz J., 2018, Ttumacz między innymi. Szkice o przektadach, jezykeach i literaturze, Wrocław. Kowalczyk J.R., br, Olga Tokarczuk, „Prowadź swój plug przez kości umarlych”, https:/ / culture.pl/ $\mathrm{pl}$ /dzielo/olga-tokarczuk-prowadz-swoj-plug-przez-kosci-umarlych [dostęp: 28.01.2020]. Kubaszczyk J., 2016, Faktura oryginału i przekładu. O przektadzie tekstów literackich, Warszawa. Legouis E., 1968, A short history of English Literature, trans. Boyson V.F., Coulson J., London. Miłosz C., 2007, Historie ludzkie, „Zeszyty Literackie” [Warszawa - Paryż], nr 5.

Miłosz C., 2015, Præekłady poetyckie wszystkie, Kraków. 
Nowacki D., 2009, Prowadź swój plug przez kości umarlych, https://wyborcza.pl/1,75410,7285 172,Prowadz_swoj_plug_przez_kosci_umarlych_Tokarczuk_html [dostęp: 28.01.2020]. Sławkowa E., 2016, Tekst literacki w kregu jezykoznawstwa, t. II, Katowice.

Święch J., 2016, Drieje ttumaczeń, czyli o historii, której nie ma, „Postscriptum Polonistyczne”, nr 2. Tokarczuk O., 2016, Prowadź swój plug prz̨ez kości umarlych, Kraków.

Михајловски А., 1991, Вилијам Блејк: Венчавката на рајот и пеколот (notatki), в: Нераспнати богови. Од Аан до Расел, Скопје.

Џепаровски И., 2013, Вилијам Блејк - имагиначија и креачија (роstowie), в: Вилијам Блејк. Избрани дела, Скопје.

Lidija Tanuševska - prof. dr hab., Uniwersytet św. św. Cyryla i Metodego, Skopje, Macedonia.

Pracuje w Katedrze Slawistyki na Wydziale Filologicznym im. Blaże Koneskiego Uniwersytetu św. św. Cyryla i Metodego w Skopje w Macedonii, gdzie prowadzi zajęcia z literatury polskiej oraz praktyki przekładu z języka polskiego na macedoński. Jej zainteresowania badawcze obejmują głównie zagadnienia przekładoznawstwa, ale również językoznawstwa porównawczego i literaturoznawstwa. Jest wybitnym tłumaczem literatury polskiej na język macedoński. Została wyróżniona kilkoma nagrodami translatorskimi, m.in. Nagrodą im. Ryszarda Kapuścińskiego za przekład Imperium na nowy język (2015) i Złote Pióro Macedońskiego Stowarzyszenia Tłumaczy Literackich w 2008 roku za przekład Prawieku i innych czasów Olgi Tokarczuk. W 2017 roku wydała monografię Przyczynek do gramatyki konfrontatywnej języka macedońskiego i języka polskiego. Przełożyła powieści Bieguni i E.E. Olgi Tokarczuk, a także opowiadania i nowele Cypriana Kamila Norwida, Brunona Schulza, Stefana Grabińskiego i in.

Kontakt: lidkapol@yahoo.com 